JaKUB MATEusz ŁaCH

Politechnika Wrocławska, Polska - Wroclaw University of Science and Technology, Poland

\title{
Wpływ wielkości układów regionalnych na wyniki wyborów na przykładzie symulacji alternatywnej ordynacji
}

\section{Influence of the Size of Regional Systems on the Results of the Election Based on the Example of Simulation of Alternative Ordinance}

Streszczenie: Wyniki wyborów w Stanach Zjednoczonych z 2016 r. dla wielu Polaków były szokiem, gdyż część osób nie rozumie, na jakiej podstawie Hillary Clinton, która zdobyła więcej głosów w wyborach ogólnych, mogła przegrać walkę o prezydenturę z Donaldem Trumpem. Wytłumaczenie tego jest jednak dość proste - to zasługa elektorskiego systemu wyboru prezydenta i wiceprezydenta USA. W niniejszym artykule autor przedstawia i porównuje obowiązujące prawnie drogi wyboru najwyższych przedstawicieli władz w Polsce i USA. Artykuł oprócz tego, że ma celu na przybliżyć działanie amerykańskiej ordynacji w praktyce, ukazuje możliwości wprowadzenia takiego rozwiązania w Polsce. Praca uwzględnia także symulację takiego systemu wyborczego, powołując się na wyniki prezydenckiej elekcji w Rzeczypospolitej z roku 2015. Niniejszy artykuł akcentuje także skład i ewentualny podział hipotetycznego nowego organu władzy, jakim byłoby Kolegium Elektorów III Rzeczpospolitej. Ponadto w tekście zwrócono uwagę na różne negatywne zjawiska wynikające z możliwości wpływu polityków na ordynacje, przywołując pojęcie gerrymanderingu oraz obrazując je na jednym z przykładów.

Abstract: The results of the US elections in 2016 were a shock for many Poles, as the majority of us do not understand why Hillary Clinton lost despite having more votes in the popular vote. The explanation of this is quite simple, in the USA there is an electoral system of electing the president and vice-president. The author presents and compares ways of choosing the highest representatives elected to Presidential Palace and the White House. The article, apart from presenting the American ordination in practice, shows the possibilities of introducing such a solution in Poland. The text also includes a simulation of such an electoral system, using the results of the presidential election in Poland in 2015. This article also presents the composition and possible division of a hypothetical new authority that would be the Electoral College of the Third Republic of Poland. In addition, the text shows various negative phenomena resulting from the possibility of the influence of politicians on the ordination invoking "gerrymandering" and depicting it on one of the examples.

Słowa kluczowe: gerrymandering; kolegium elektorskie; ordynacja; prezydent; wybory

Keywords: elections; electoral college; gerrymandering ordination; president 
Otrzymano: 11 listopada 2017

Received: 11 November 2017

Zaakceptowano: 15 maja 2018

Accepted: 15 May 2018

\section{Sugerowana cytacja/Suggested citation:}

Łach, J.M. (2018). Wpływ wielkości układów regionalnych na wyniki wyborów na przykładzie symulacji alternatywnej ordynacji. Przedsiębiorczość - Edukacja [Entrepreneurship - Education], 14, 518-521. DOI: 10.24917/20833296.14.36

\section{Obecna ordynacja wyborcza}

W Europie i Stanach Zjednoczonych system prezydencki jest jednym z filarów demokracji. Ordynacja wyborcza powiązana z władzą wykonawczą jest różna w wielu krajach, wspólne jest jednak to, że w każdym państwie tzw. pierwszego świata system ten jest jawnie i wyczerpująco opisany w aktach prawnych.

W Rzeczypospolitej Polskiej wyboru prezydenta dokonują pełnoletni obywatele posiadający czynne prawo wyborcze. Aby startować na urząd Prezydenta RP, wymagane jest ukończenie 35 roku życia i zebranie przed kampanią 100000 podpisów dorosłych obywateli RP. Aby zostać wybranym, wystarczy zdobyć ponad połowę wszystkich oddanych i ważnych głosów (system 50\% + 1, tzw. większości bezwzględnej). Jeżeli żaden z kandydatów nie dokona tego w pierwszej turze, odbywa się druga tura, w której zmagają się dwaj kandydaci najlepsi w pierwszej turze - tutaj już, zgodnie z prostymi zasadami matematyki, ktoś musi zdobyć co najmniej 50\%. W naszym kraju frekwencja nie jest istotna przy tego typu wyborach - do urn mogą iść wszyscy albo tylko jedna osoba - w każdej z tych sytuacji wybór będzie ważny i uznany przez Państwową Komisję Wyborczą. Prezydent wybierany jest na pięcioletnią kadencję, po której może ubiegać się o jedną reelekcję.

W ostatnich wyborach prezydenckich w roku $2015 \mathrm{w}$ pierwszej turze zwyciężył Andrzej Duda, który zdobył 34,76\% głosów, a w drugiej turze przypieczętował swoje zwycięstwo, zdobywając 51,55\% głosów.

\section{Amerykański system elektorski}

W Stanach Zjednoczonych wyboru prezydenta i wiceprezydenta nie dokonują mieszkańcy kraju w głosowaniu powszechnym. Ich głosy decydują o przynależności partyjnej elektorów reprezentujących dany stan. Przedstawiciele 50 stanów i Dystryktu Kolumbii to łącznie 538 osób, które w ramach Kolegium Elektorów Stanów Zjednoczonych wybierają dwie najważniejsze osoby w państwie.

Aktualna liczba elektorów przypadająca na stan została ściśle określona w Cenzusie z 2010. Na jego mocy liczby obowiązują w wyborach w latach 2012, 2016 i 2020.

W każdym stanie, oprócz Nebraski i Maine, gdzie istnieją dodatkowo wydzielone JOW-y, działa zasada winner-take-all. To oznacza, że wystarczy przewaga jednego głosu, aby pełna pula elektorów trafiła na konto danego kandydata. Dla przykładu Dystrykt Kolumbii dysponuje 3 głosami elektorskimi, Karolina Południowa - 9, a Kalifornia - aż 55. System ten działa od pierwszych wyborów na Prezydenta Stanów Zjednoczonych w 1789, a identyczny istniał w Stanach Skonfederowanych. 
W ostatnich wyborach z 2016 r. zwycięstwo odniósł kandydat Partii Republikańskiej Donald J. Trump, który pomimo przegranej w ogólnej liczbie głosów mieszkańców, wygrał w liczbie głosów elektorskich z kandydatką Partii Demokratycznej Hillary D. Clinton 304 : 227. Kilku elektorów wyłamało się z przysięgi danej swojej partii oraz mieszkańcom swojego stanu i zagłosowało na innego kandydata. Jeden głos elektorski, która powinna otrzymać Clinton, przypadł rdzennej Amerykance - Faith Spotted Eagle. Były to piąte wybory w historii USA, gdzie przegrany zdobył więcej głosów mieszkańców niż przyszły prezydent.

\section{Kolegium elektorskie w Polsce}

Alternatywna ordynacja, o której piszę w tytule, to nic innego jak właśnie system elektorski, który chciałbym przenieść ze Stanów Zjednoczonych do Polski. Najważniejszymi podmiotami w tym systemie byłyby oczywiście okręgi i Kolegium Elektorów Rzeczypospolitej Polskiej. W naszym kraju nie mamy niestety stanów, dlatego okręgami z przypisanymi elektorami byłyby powiaty; obecnie istnieje ich równo 380. Dzięki obliczeniom i danym zaczerpniętym z PKW wyznaczyłem ostateczną liczbę 1882 elektorów. Tak wysoki wynik bierze się z faktu, iż starałem się, aby w całym kraju współczynnik wyborców do elektorów był taki sam, a jest to dość utrudnione przez rozbieżności w liczbie mieszkańców różnych powiatów - od 20417 w powiecie sejneńskim do 1753977 w Mieście Stołecznym Warszawa. Ostatecznie współczynnik został ustalony na poziomie nieco ponad 20000 mieszkańców na jeden głos elektorski. W związku z tym powiatowi ze stolicą w Sejnach przysługuje jeden głos, a Warszawie - aż 85 głosów.

Dla przykładu tej alternatywnej ordynacji wziąłem pod uwagę II turę wyborów prezydenckich, czyli zaciętą walkę pomiędzy Bronisławem Komorowskim a Andrzejem Dudą. Jak wspomniałem wyżej, kandydat Prawa i Sprawiedliwości zdobył 51,55\% głosów i został on piątym Prezydentem Rzeczypospolitej Polskiej. W systemie elektorskim z zasadą, że zwycięzca bierze wszystko, wybory wygrałby kandydat ubiegający się o reelekcję stosunkiem głosów 1043 : 839, pomijając sprawę wiarołomnych elektorów.

\section{Województwo opolskie}

Przechodząc do pierwszego członu tytułu, czyli do wpływu wielkości okręgów na wyniki wyborów, pokrótce przedstawię sytuację województwa opolskiego w alternatywnej ordynacji, ponieważ ta część Polski posłuży mi jako przykład w dalszej części projektu.

W ordynacji na wzór amerykański, lecz na przykład przy podziale kraju na województwa, B. Komorowski zdobyłby pełną pulę 49 głosów elektorskich. Przy podziale na powiaty zwycięzca w województwie nie zmieniłby się, ale Andrzej Duda wygrałby w kilku okręgach, co zmienia wynik z 49 : 0 na 36 : 13 dla byłego prezydenta. Różnica nieduża przy puli 1882 głosów do zdobycia, lecz ta „pechowa 13” mogłaby zaważyć na wyniku w skali całego kraju.

Jak wpłynąć na potencjalną liczbę elektorów przy uchwalaniu ordynacji?

Na wyniki najłatwiej wpłynąć przez zmiany terytorialne okręgów m.in. podczas uchwalania lub zmieniania ordynacji wyborczej. Okręgi można likwidować i wchłaniać do większych i pewniejszych układów. Na przykład powiat brzeski można połączyć z powiatem 
opolskim, dzięki czemu Andrzej Duda straciłby jeden z okręgów, więc elektorzy przypisani do powiatu brzeskiego zmieniliby kandydata, na którego muszą oddać swój głos. Warunkiem takiego przypadku jest fakt, że w połączonych powiatach brzeskim i opolskim nadal zwycięzcą byłby Komorowski. Umiejętne łączenie okręgów, powiatów ze sobą mogłoby doprowadzić do sytuacji, że Komorowski zdobyłby pełną pulę 49 elektorów przypisanych do województwa opolskiego, pomimo iż przed naszą reformą systemu elektorskiego i podziału na okręgi musiał, w tych samych wyborach, uznać wyższość aktualnego prezydenta $w$ trzech powiatach i podziałem głosów elektorskich w proporcji $36: 13$, jak wspomniałem powyżej.

Kolejną przyczyną zmiany wyniku wyborów może okazać się tworzenie dodatkowych okręgów, wydzielanie nowych powiatów z większych jednostek terytorialnych, aby przejąć część głosów z puli powiatu sprzed reformy. Za przykład możemy posłużyć się wydzieleniem powiatu Nysa - Głuchołazy z większego powiatu nyskiego. Spowodowałoby to wzrost liczby elektorów Komorowskiego przy jednorazowym spadku liczby elektorów Dudy.

\section{System elektorski w Europie}

Znaczna większość Polaków, jak i ogólnie Europejczyków, nie zdaje sobie jednak sprawy, że system elektorski w naszym regionie to nie tylko marzenia zafascynowanych amerykańską historią i ordynacją politologów. Każdy dorosły obywatel Unii Europejskiej tak naprawdę bierze udział w pewnego rodzaju głosowaniu elektorskim. Mowa tutaj oczywiście o wyborach na przewodniczącego Rady Europejskiej. Obywatele krajów członkowskich głosują w wyborach krajowych na partię, która wprowadza swojego człowieka na Prezesa Rady Ministrów, który potem w Brukseli bierze udział w wyborze przewodniczącego Rady Europejskiej. Różnica pomiędzy opisanym przeze mnie wcześniej systemem elektorskim w USA i alternatywnym systemem w Polsce a systemem w Unii Europejskiej jest jedna: przy wyborze w Radzie Europejskiej każdy kraj, każdy rząd ma jeden głos, niezależnie od liczby mieszkańców danego państwa.

Jakub Mateusz Lach, student I roku Politechniki Wrocławskiej na kierunku matematyka i statystyka. Interesuje się polityką, światem pieniądza, a także sportem. Poza karierą naukową jest związany z klubem futbolu amerykańskiego Panthers Wrocław, w którym świętował sukces Mistrzostwa Polski PLFA2 w 2017 r. Swoje wszechstronne zainteresowania i możliwości stara się wykorzystywać w życiu prywatnym oraz zawodowym, np. w czasie samorządowej kampanii wyborczej we Wrocławiu. Przyszłość wiąże z polityką lokalną i sektorem finansowym.

Jakub Mateusz Lach, first-year student of the Wrocław University of Science and Technology. He studies mathematics and statistics. He is interested in politics, world of money and sport. In addition to studies he is an American football player in Panthers Wroclaw with whom he won 2017 PLFA2 Polish Championship. He uses his interests and abilities in private life and for example in campaign of local government elections in Wrocław. In the future, he would like to work in local politics and the financial sector.

\section{Adres/Address:}

Politechnika Wrocławska

Wydział Matematyki

ul. Janiszewskiego 14a

50-372 Wrocław, Polska

e-mail: jakub.mateusz.lach@gmail.com 